\title{
PLASTIC SURGERY IN UKRAINE: LEGAL ASPECT
}

\author{
Yaroslav Tsekhmister \\ First Vice-Rector on Scientific Pedagogical Activity \\ Bogomolets National Medical University \\ 13 T. Shevchenko blvd., Kyiv, Ukraine, 01601 \\ Ya.Tsekhmister@gmail.com \\ Oleksandra Lysenko \\ Deputy Director of the Institute of Postgraduate Education \\ Bogomolets National Medical University \\ 13 T. Shevchenko blvd., Kyiv, Ukraine, 01601 \\ A.Yu.Lysenko@gmail.com
}

\begin{abstract}
The article highlights the problem of plastic surgery legal status in Ukraine, in particular describes the absence of postgraduate study programs for doctor-specialist in plastic surgery qualification award in comparison with the process of plastic surgeons training in the USA. Also describes some steps for separation of plastic surgery as an independent specialty in Ukraine in particular the resolution of the XXIII Congress of Surgeons of Ukraine (Kyiv, Ukraine, 2015) which announced the proposals on the introduction of the specialty "Plastic and Reconstructive Corrective Surgery" in the list of medical specialties, as well as to approve the draft order by the Ministry of Health of Ukraine, "On the improvement of medical aid in plastic surgery to population in Ukraine", developed by the All-Ukrainian Association of Plastic, Reconstructive and Aesthetic Surgeons. As well the research analyzes the potential responsibility for plastic operations performing by a physician whose qualification is not confirmed as "Doctor-Plastic Surgeon" due to the existing legal collision. The necessity of a term "cosmetic interference" official definition is present, in particular, it defines the importance of the legal definition of the term "cosmetic interference" in the context of sick leave certificate design because according to the legislation of Ukraine, disability payments due to "cosmetic interference" are not provided while that the diagnosis in a sick leave certificate can be mentioned only because of the written consent of the person to whom it is issued. Besides the paper presents the examples of court cases and legislation that confirm the necessity to regulate the legal status of plastic surgery in Ukraine.

Keywords: plastic surgery, postgraduate education, medical specialties in Ukraine.
\end{abstract}

\section{Introduction}

Plastic surgery as a section of surgery that is directed to remove any deformations and defects of an organ, tissue or surface of a human body or correction of visible physiological changes [1], is known to the humankind since the ancient times. Thus, the papyrus by Edwin Smith - transcription of the ancient Egyptian medical text, one of the oldest famous surgical treatises $(3,000-$ 2.500 B. C.) describes the plastic surgery of a broken nose [2].

The modern tendency in the development of plastic surgery is its aesthetic direction as the most plastic operations have no reconstructive function. Thus, according to the data from the American Association of Plastic Surgeons in 2016 its members made over 17 million aesthetic plastic operations, among them $89,7 \%$ were minimally invasive. The total number of reconstructive plastic operations for the analogous period is a bit less than 6 million. The widest spread surgical interferences with aesthetic purpose are breast augmentation, lipoplasty, rhinoplasty, blepharoplasty and tuck-up operation [3].

\section{Aim of research}

To determine the current state of plastic surgery legal regulation in Ukraine and to define the perspectives for its improvement.

\section{Materials and Methods}

During the article was prepared such informational materials were used: regulatory documents, statistical data, lawsuits relating to the doctors' education and medical practice in Ukraine. 
The aim of the research was achieved by such methods:

- dialectical - to study the general theoretical aspects of the plastic surgeons' education and plastic surgery practice;

- formal-logical - to research legislation for medical care and medical services provision;

- specific sociological research - for judicial practice study;

- dogmatic (logical) analysis - for formulation of conclusions and proposals taking into account requirements in relation to certainty, consistency, consistency and validity judgments within the theoretical and legal constructions.

\section{Result and discussion}

The official statistics for a number of plastic operations in Ukraine is not run but due to some data approximately 15,000 such operations are made per year with aesthetic purpose. That's why, the issue about legal regulation of plastic surgery in Ukraine acquires more and more actuality [4].

As it has already been mentioned, in the United States of America that is the leader due to a number of plastic operations per year $(20 \%$ from a total number of plastic operations in the world [5], the persons, who successfully passed through 6 years' program of postgraduate education at residency in plastic surgery, or who passed through 3 years' residency in general surgery and 3 years' residency in plastic surgery, are entitled to perform them. There are the programs of one-year specialization for plastic surgeons, who wish additionally to acquire a narrow sub-specialty [6].

The competence of plastic surgeon in the United States of America includes the examinations of patients with inborn deformations or defects, arisen as a result of disease or trauma, fulfilment of operative interferences with the purpose of correction, reconstruction or recovery of physical or functional defects, as well as the fulfilment of operative interferences with aesthetic purpose [6].

In Ukraine there is no opportunity for postgraduate study to acquire the title of doctor-specialist in plastic surgery, as Occupational Classification DK 03:2010 and, accordingly, "Handbook of Qualification Characteristics for Occupations of Workers" has no occupation "Doctor-Plastic Surgeon". Thus, in practice the doctors of surgical specialties, who passed through the courses of advanced studies in Ukraine or abroad in plastic surgery or its certain sections, are admitted to perform the plastic operations.

In order to improve the plastic and reconstructive surgical aid to the population of Ukraine, the Ministry of Health of Ukraine issued the order No 210, dd. 02, April, 2009, which in particular, regulated the procedure for special training of doctors-surgeons in plastic and reconstructive surgery, as well as approved the typical job description of doctor-surgeon, structural subdivision of health care facility, which will render the specialized medical aid in plastic and reconstructive surgery [7]. However, the abovementioned regulatory legal act was cancelled according to the order by the Ministry of Health of Ukraine No 660, dd. 06, August, 2010, as the one that was subject to state registration and was not registered at the Ministry of Justice of Ukraine [8].

It should also be mentioned that according to the resolution of the XXIII Congress of surgeons of Ukraine that was held on 21-23, October, 2015 in Kyiv, Ukraine they announced the proposals about introduction of the specialty "Plastic and Reconstructive Corrective Surgery" into the list of medical specialties, as well as to approve the draft order by the Ministry of Health of Ukraine "About the improvement of medical aid in plastic surgery to the population in Ukraine", developed by the All-Ukrainian Association of Plastic, Reconstructive and Aesthetic Surgeons [5]. However, the issue about admission of doctors under the specialty "Surgery" to perform the plastic operations in Ukraine still remains unsolved on legislative basis.

The draft order is designed to regulate the activities of healthcare institutions and doctors in the field of plastic surgery. The introduction of the medical specialty "Plastic Surgery" will improve the quality and increase the clinical and economic efficiency of medical care. According to the project, plastic surgery as a part of medical care, provides a complex of medical and rehabilitation measures aimed at [5]: 
- elimination of anatomical and functional defects of the covering tissues and structures adhering to them, different localization, arising from birth defects, acute injuries and their implications, diseases and surgical interventions (reconstructive plastic surgery);

- removal of defects of the covering tissues and structures adhering to them, different localization, which arise as a result of age-related changes, as well as making corrections to their appearance at the request of patients (aesthetic plastic surgery).

Reconstructive and plastic operations help to eliminate deformations, defects of tissues and organs, and restore their functions by methods of plastic surgery. Today, such operations are carried out to all who received bodily injuries as a result of injury, illness or have birth defects. The need for such operations has increased dramatically due to the large number of patients wounded in combat operations in the antiterrorist operation (ATO) area. Successful reconstructive surgery can radically change the quality of life of a person and help to restore a sense of high-grade life.

It is clear that in cases when a patient remains satisfied with an aesthetic result from a performed surgical interference, and no harm was made to his/her life and health during a plastic operation, the issues about training of medical personnel are passed by. However, in case if there are any issues about indemnification of harm, caused by a handicap, other injury of health or death of a natural person, the medical qualification is extremely important both in terms of patients' protection and protection of doctors themselves.

Analysing the regulatory legal acts that settle the issues, related to the medical activity, within this context, we should pay our attention to provisions of Art. 138 in the Criminal Code of Ukraine, which anticipates the liability for "Engagement into medical activity without a special permit, made by a person, who does not have any proper medical education if it caused to severe consequences for a patient...”.

Consequently, the medical activity is considered illegal under the conditions when it is performed: without a special permission; by a person who does not have proper medical education.

"Special permit" is a document confirming the compliance of a specific person with the qualification requirements for the conduct of medical activity in the field of native and non-traditional medicine, subject to the mandatory control of such activities by the doctor [9].

A compulsory condition for the unlawfulness of medical activities is the exercise of such activity by a person who does not have proper medical education. A proper medical education should be considered a set of knowledge that according to the current legislation gives the right to engage in medical activities of a certain type. Thus, persons of unlawful medical activity may be persons: who do not have a formal education at all; who have medical education but do not perform medical activity in accordance with the specialty and/or level of training received.

As it concerns the "proper" medical education, so, taking into consideration that the programs of postgraduate education for acquisition of the title doctor-specialist under the specialty "Plastic Surgery" are absent in Ukraine today, this issue remains unsettled on the legislative basis and in case of any judicial disputes it may be interpreted only due to own understanding and persuasion of court.

Considering the judicial practice, related to the issue about appliance of medical education at doctors, we find the confirmation for actuality of the problem, raised by us, namely within the context of plastic surgery. Thus, in the criminal case No 334/3532/13-k person 4, doctor of the highest qualification category under specialties "Surgery" and "Proctology" was accused of committing the crimes, anticipated by Art. 138, 140 P. 1 in the Criminal Code of Ukraine. According to the plot of the case person 5 addressed to person 4 together with the daughter - person 6 - as to endoprosthesis replacement of lacteal glands to the latter one and performance of augmentation mammoplasty. After the planned operative interference was performed by the surgeon - person 4 with participation of the surgeon - person 8 and the anaesthesiologist - person 9, person 6 had the cardiac arrest. The reanimation measures were started, during which the anaesthesiologist - person 9 made the single hard blunt wound to suffered person 6 by a medical catheter in the right clavicular region that caused to the inju- 
ry of the subclavicular vein, intercostal muscles, parietal pleura and tissues of the right lung that led to development of hemopneumothorax, which was not diagnosed by the operating surgeon - person 4 and caused to death of patient.

During the prejudicial investigation the actions of the accused - person 4 were classified according to Art. 138 in the Criminal Code of Ukraine as the engagement in medical activity without a special permit by a person, who has no proper medical education, however, according to the court sentence this accusation found no its confirmation during judicial investigation as the court established that accused person 4 had the higher medical education that is confirmed by a diploma under the specialty of medical care, certificates of doctor-specialist under the specialties "Surgery" and "Proctology", valid certificate from the Health Care Department at Regional State Administration about award of the highest qualification category under the specialty "Surgery", as well as a working experience at the post of doctor-surgeon for over 30 years [10].

However, taking into consideration the fact that Ukraine is referred to the continental system of law, where a legal precedent is not a source of law, this judgment cannot be dogmatic and another judgment may be taken at the origin of similar judicial disputes. That's why the issue about proper medical education of surgeons, who make plastic operations, must be determined at the level of legislation.

The issue about the temporary disability of a worker, in particular, appointment of material provision under general compulsory state social insurance requires the special attention within the context of absence of legal settlement of issues on plastic surgery in Ukraine, in particular, as it has been mentioned above, absence of a possibility for licensing of health care facility to implement the medical practice under the specialty "Plastic Surgery".

According to Art. 51 in the Law of Ukraine "About general compulsory state social insurance in connection with a temporary loss of working capacity and expenses, stipulated by burial", the ground to appoint the assistance for the temporary disability is the sick leave certificate, issued due to the established procedure [11]. As it is mentioned in s. 1.5.2 "Instruction about procedure for issue of documents that certify the temporary disability of citizens", approved by the order from the Ministry of Health of Ukraine, dd. 13, November, 2011 No 455, "the attending physicians at medical preventive establishments from all patterns of ownership at cosmetic interference without medical indications" are not entitled to issue the sick leave certificates.

At once it is necessary to mention that the concept "cosmetic interference" has no official interpretation and is not used in other regulatory legal acts, related to medical activity, however, taking into account the analysis of foreign literature, we can assume that it means namely the plastic operations, which are made only with an aesthetic purpose and have no reconstructive function.

In this case it is necessary to pay the attention to the procedure to fill in the sick leave certificate, defined by instruction, approved by joint order from Ministry of Health of Ukraine, Ministry of Labour and Social Policy of Ukraine, Temporary Disability Insurance Fund, Social Insurance Fund from Occupational Accidents and Diseases of Ukraine, dd. 03, November, 2004 No 532/274/136-oc/1406. Thus, s. 3.2 in "Instruction about procedure to fill in the sick leave certificate" defines that filling in the lines "Primary diagnosis" and "Final diagnosis" is made only due to the written consent of a patient, and at absence of such one, the abovementioned information is not specified [12].

We think that it is necessary in more details to consider the grounds for introduction of changes into the abovementioned regulatory legal act and to set forth s. 3.2 in current wording. In particular, we shall pay our attention to the directive by Pecherskyi District Court in Kyiv, dd. 25, July, 2006 No 2-A-216-1/06 under the administrative suit from person 1 against the Ministry of Health of Ukraine, Ministry of Labour and Social Policy of Ukraine, Temporary Disability Insurance Fund, Social Insurance Fund from Occupational Accidents and Diseases of Ukraine about illegality of the regulatory legal act in the part that anticipates the placement 
of information in the sick leave certificate about the primary and final diagnosis mentioning the code of diagnosis according to the International Statistical Classification of Diseases and Associated Health Care Problems from the tenth revision, adopted by $43^{\text {rd }}$ World Assembly of Health Care on 01, January, 1993.

Person 1 grounded its administrative suit by the fact that according to the previous wording (being valid as of the suit) of "Instruction about procedure to fill in the sick leave certificate", in the appropriate line of the sick leave certificate a doctor shall specify the diagnosis (primary and final) of the person, who received the sick leave certificate. Thus, at attendance and submission of the sick leave certificate to the employer, the confidential information about person's health status contradicts to Art. 32 in Constitution of Ukraine about prohibition “... for collection, preservation, use and distribution of confidential information about person without his/her consent...”.

Pecherskyi District Court in Kyiv satisfied the suit, having referred to Art. 3, 19, 21, 22, 32 , 55, 64, 68 in the Constitution of Ukraine; Art. 8 in the Convention for the Protection of Human Rights and Fundamental Freedoms; Art. 4, 6, 7, 8, 14, 40, 41 in the Law of Ukraine "Basics of legislation of Ukraine about health care"; Art. 285, 286 in Civil Code of Ukraine; Art. 23 in Law of Ukraine "About information" [13].

Thus, taking into consideration the fact that the diagnosis in the sick leave certificate can be mentioned only due to the written consent of the person, to whom it is issued, the absence of the legislative definition for the concept "cosmetic interference" as the ground for non-issue of the medical certificate, as well as fulfilment of plastic operations by doctors-surgeons at health care facilities, licensed to implement the medical practice under the specialty "Surgery", there appear the prerequisites for illegal receipt of assistance for the temporary disability by persons, who had the plastic operation only with an aesthetic purpose without a reconstructive function and at the absence of other medical indications.

\section{Conclusions}

Taking into consideration the demand on services in plastic surgery with an aesthetic purpose, analysis of the effective regulatory legal base and judicial practice, as well as with the purpose to establish the proper conditions for preservation and public health promotion, in our opinion, it is necessary to do the following:

1. To introduce the occupation "Doctor-Plastic Surgeon" into the Occupational Classification DK 03:2010 and "Handbook of Qualification Characteristics for Occupations of Workers".

2. To implement the programs of postgraduate education for acquisition of the title doctor-specialist under the specialty "Plastic Surgery"; to establish the specific regulatory legal act by the Ministry of Health of Ukraine that will define the procedure for implementation and requirements to health care facilities that will render the services in plastic surgery in Ukraine.

3. To define at the legislative level the term "proper medical education", in particular by specifying the powers for the representatives of each medical specialty.

\section{References}

[1] Fistal, E. Ya., Mishalov, V. H., Samoilenko, H. Ye. et. al.; Fistal, E. Ya. (Ed.) (2010). Plastic surgery. Kyiv: VSV "Medicine", 376.

[2] Shiffman, M. A., Di Giuseppe, A. (Eds.) (2013). Cosmetic Surgery: Art and Techniques. Springer, 1192. doi: 10.1007/978-3-642-21837-8

[3] Plastic Surgery Statistics Report. Available at: https:/www.plasticsurgery.org/documents/ News/Statistics/2016/plastic-surgery-statistics-full-report-2016.pdf Last accessed: 15.02.2018

[4] Resolution of the XXIII Surgery Congress of Ukraine (2015). Available at: http://as-ukr.org/ rezolyutsiya-xxiii-z-yizdu-hirurgiv-ukrayini/ Last accessed: 15.02.2018

[5] Shen, L. (2015). Here are the vainest countries in the world. Available at: http://www.businessinsider.com/here-are-the-vainest-countries-in-the-world-2015-8 Last accessed: 15.02.2018

[6] How to Become a Plastic Surgeon in 5 Steps. Available at: https://learn.org/articles/Plastic_Surgeon_Become_a_Plastic_Surgeon_in_5_Steps.html Last accessed: 15.02.2018 
[7] On the improvement of plastic and reconstructive surgical care for the population of Ukraine (2009). Ministry of Health of Ukraine, No. 210. 02.04.2004. Available at: http://zakon5.rada.gov.ua/rada/ show/v0210282-09 Last accessed: 15.02.2018

[8] About abolition of orders of the Ministry of Health, which were subject to state registration but not registered in the Ministry of Justice of Ukraine (2010). Ministry of Health of Ukraine, No. 660. 06.08.2010. Available at: http://zakon5.rada.gov.ua/rada/show/v0660282-10 Last accessed: 15.02.2018

[9] On the procedure for submission by the Committee on questions of folk and non-traditional medicine at Ministry of Health of Ukraine special permit for medical examination Activities in the field of folk and non-traditional medicine (2000). Ministry of Health of Ukraine, No. 195. 10.08.2000. Available at: http://zakon5.rada.gov.ua/laws/show/z0150-01 Last accessed: 15.02.2018

[10] The only state register of court decisions. Case No. 334/3532/13-k (2014). Available at: http:// reyestr.court.gov.ua/Review/40910206 Last accessed: 15.02.2018

[11] On compulsory state social insurance in connection with temporary incapacity for work and expenses caused by burial (2001). Verkhovna Rada of Ukraine, No. 2240-III. 18.01.2001. Available at: http:// zakon3.rada.gov.ua/laws/show/2240-14/ Last accessed: 15.02.2018

[12] Instruction about the order of filling the disability sheet (2004). Ministry of Health of Ukraine, No. 532/274/136-oc/1406. 03.11.2004. Available at: http://zakon2.rada.gov.ua/laws/show/z1456-04 Last accessed: 15.02 .2018

[13] About making changes to the joint order Ministry of Health of Ukraine Ministry of Labour and Social Policy of Ukraine, Social Insurance Fund from Temporary disability, Social Fund insurance against accidents at and occupational diseases of Ukraine (2004). Ministry of Health of Ukraine, No. 532/274/136-os/1406. 03.11.2004. Available at: http://zakon2.rada.gov.ua/laws/show/z1324-06 Last accessed: 15.02.2018 